Apidologie, 1984, 15 (4), 421-434

\title{
SURVIVAL AND PROPHYLACTIC CONTROL OF TROPILAELAPS CLAREAE INFESTING APIS MELLIFERA COLONIES IN AFGHANISTAN
}

\author{
Jerzy WOYKE \\ FAO Representation, Kabul, Afghanistan
}

\begin{abstract}
SUMMARY
Honeybee colonies heavily infested with Tropilaelaps clareae were found in some apiaries in Afghanistan. Only colonies moved for winter to warmer areas where interruption of brood rearing did not occcur, were invaded, while those overwintered in colder areas were free of mites. From 2 to $54 \%$ of brood cells were infested in particular colonies, but only $1.5 \%$ of adult bees were invaded.

T. clareae mites on combs with eggs or on adult bees can survive for 1-2 days only. Adult mites are unable to feed on hemolymph of adult bees.

Three methods are described to combat Tropilaelaps. Invasion of Apis mellifera by $T$. clareae in temperate zones where winter interruption of brood rearing occurs is not expected. But $T$. clareae can create real problems for beekeeping in tropical zones of all continents.
\end{abstract}

\section{INTRODUCTION}

The major difficulty encountered after the introduction of Apis mellifera into tropical Asia was caused by the ectoparasitic bee mite Varroa jacobsoni, which naturally parasitizes Apis cerana, and Tropilaelaps clareae, which parasitizes Apis dorsata (Crane, 1968 ; Kevan et al., 1984). Invasion of $A$. mellifera colonies by $T$. clareae appears to be more destructive than that by $V$. jacobsoni and some believe that $T$. clareae could become a more serious pest of honeybees worldwide than $V$. jacobsoni (BURGETT et al., 1983).

The major question regarding $T$. clareae concerns its potential escape from tropical Asia and whether it could become established on $A$. mellifera in temperate regions (BURGETt et al., 1983 ; BURGETt and Krantz, 1984). 
Adult $T$. clareae can survive without food for two days (Akratanakul, 1984). Depriving colonies of brood by destroying it or by caging the queen for 21 days decreases the mite population.

The life span of $T$. clareae on adult bees has not yet been recorded. This was the main question studied in the present investigation. I have also tested a method to combat the mite without the use of drugs. Some of these investigations should be repeated and some results verified. However, due to the urgency of this problem I wish to present some preliminary results.

\section{MATERIAL AND METHODS}

This investigation was conductced in Afghanistan (WoYKE, 1984) in the area of Kabul in 1983-84.

The presence of $T$. clareae in bee colonies was detected by uncapping sealed brood and searching for mites running on the surface of brood combs. More detailed investigations of brood invasion by $T$. clareae were conducted under a stereomicroscope. 50-100 sealed cells were opened and the number of cells invaded as well as the number of nymphs and adult mites in the individual cells were recorded. To determine the invasion of adult bees by the mite, several samples of about 150 to 350 bees were collected from various colonies and then killed and washed in petroleum. The number of mites fallen down by themselves was recorded under stereomicroscope.

To study survival of $T$. clareae, living mites were collected. A sharpened match stick or two preparatory needles were used to remove mites from cells and transfer them for observation.

Pieces of combs with honeybee eggs only were put in petri dishes. To each of three dishes were added 6-25 mites taken from sealed brood cells. One dish was left at room temperature (ca $25^{\circ} \mathrm{C}$ ) and the two others were placed between the brood chamber and honey super in a bee colony.

Mites were also placed one per bee in test tubes together with spinning honeybee larvae, or pupae or engorged adults. The opening of the tube was closed with a cloth. The tubes were kept in an upright position and a drop of liquid honey was put on the cloth. Test tubes with bees and mites were kept at room temperature (about $25^{\circ} \mathrm{C}$ ) or placed in an incubator or within a special isolator in the nest of a bee colony between two combs with brood.

To combat the mites, queens were confined in cages within the colony. Combs with brood were removed, or cappings were cut off after all cells with larvae were sealed.

To detect the number of mites fallen on the bottom board, metallic mesh was placed $2 \mathrm{~cm}$ above the bottom with white paper beneath it. All the debris was periodically collected and examined under a stereomicroscope for the presence of $T$. clareae.

\section{RESULTS}

1. T. clareae on Apis dorsata

A. dorsata is the original host of the parasitic mite $T$. clareae. The mite was observed by the author in nests of $A$. dorsata in 1974 in Poona, India. 
Brood comb infested by $T$. clareae had a characteristic appearance. Sealed brood cells were left in the area where bees had already emerged (Fig. 1). Dead brood infested by the mite was found in those cells.

A. dorsata was not recorded from Afghanistan, but it is present in Pakistan not far from the Afghan border.

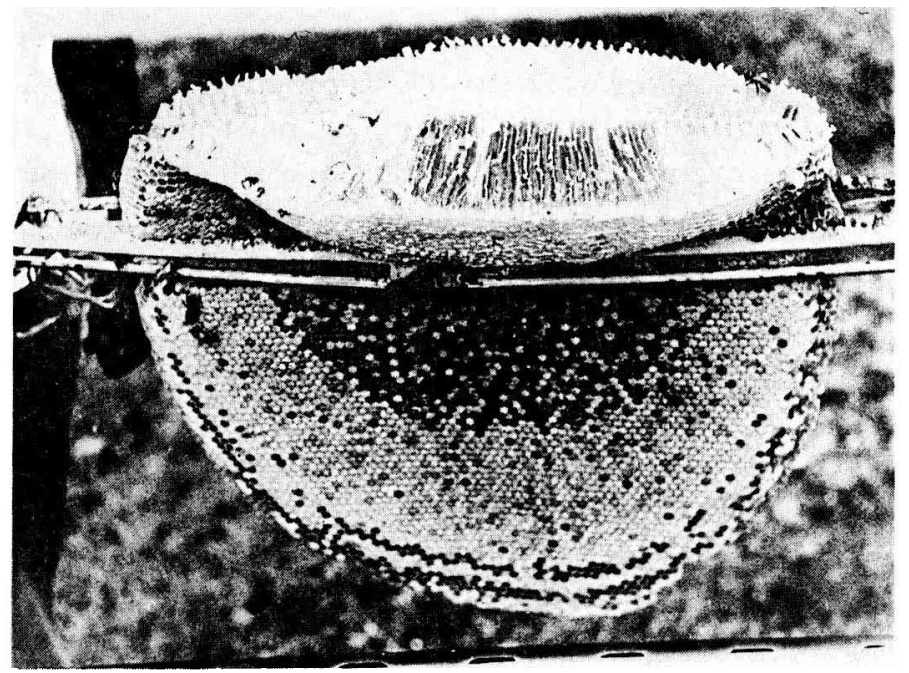

FIG. 1. - Comb of Apis dorsata infested by Tropilaelaps clareae

\section{Occurrence of ectoparasitic bee mites in Afghanistan}

It has been claimed that $90 \%$ of the colonies of $A$. mellifera in Afghanistan were lost due to ectoparasitic mites.

The author found that out of 3000 bee colonies in the Ministry of Agriculture, only $150(5 \%)$ were left.

No $V$. jacobsoni was found in the honey bee colonies examined in the Kabul area, though this mite was present to some extent in 1982 (CzMARLICKI, pers. communication). On the other hand, some colonies were heavily infested with $T$. clareae. Some very strong colonies were observed in July 1983. They had 8 Dadant frames of brood, occupied two story hives, and had supers full of honey. Their brood was infested at the rate of $20 \%$. By October both brood as well as workers had almost disappeared.

In May 1984 colonies moved to Kabul from the tropical Ningrahar district had only 3 combs of brood, occupied no more than 6 combs total and had no 
cells filled with honey. Some colonies were practically dying. At the same time, uninfested colonies had 8 to 10 combs of brood, occupied two story hives and collected $1.5 \mathrm{~kg}$ of nectar per day. While some apiaries were heavily infested, others were completely free of $T$. clareae. However, beekeepers acknowledged that mites had been present in these apiaries in previous years.

Detailed inquiries showed that colonies which were wintered in warmer areas (e.g. near Jalalabad) were infested by $T$. clareae and those wintered in colder areas (e.g. Kabul) were not. In the warmer areas brood is reared all year, while in the colder ones brood rearing is interrupted in winter. The hypothesis was made that the mite can not survive long without feeding on bee brood. To verify this, bee colonies invaded by $T$. clareae were left untreated in the autumn of 1983 to overwinter in Kabul. Interruption of brood rearing occurred for two months. In the spring of 1984 no mites were found in these colonics. T. clareae did not survive the winter without bee brood.

\section{Invasion of brood and adult worker bees by $\mathrm{T}$. clareae}

Honeybee brood infested with $T$. clareae is scattered (Fig. 2). Somc cells were opened and pupae partly eaten by the bees were visible. $T$. clareae mites running on brood combs were noticed. After cappings on brood cells are opened, brown adult mites and white nymphs were visible. Released adults run very quickly in and out of cells. In addition to dead larvae and pupae, many incomplete pupae were found in sealed cells. Thus infested larvac apparently had difficulties pupating.

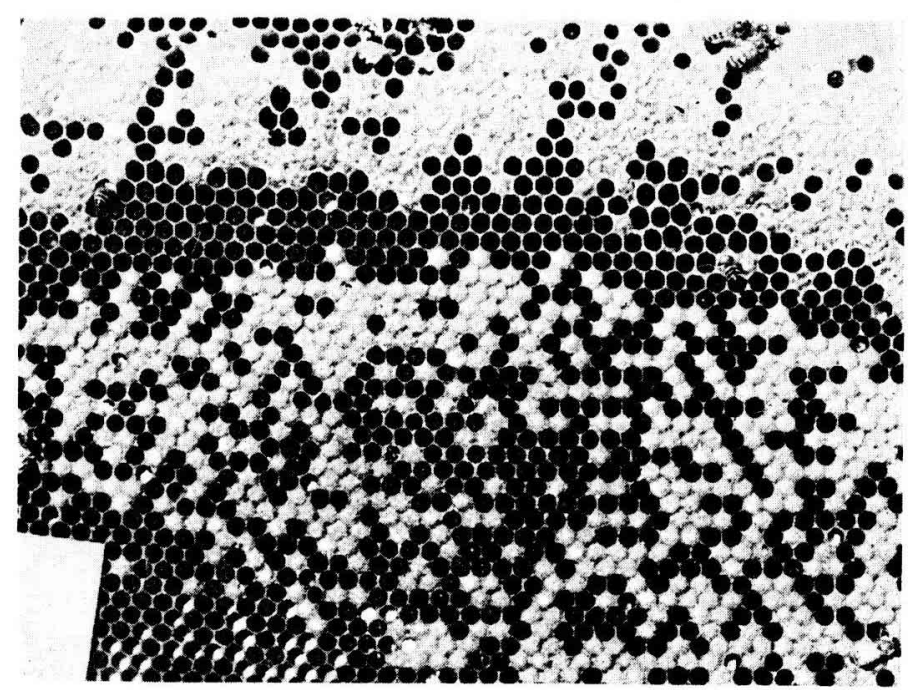

Fig. 2. - Scattered brood of a mellifera-colony infested with Tropilaelaps clareae (autumn 1983) 
On the other hand, $T$. clareae mites normally were not visible on adult worker bees in infested colonies. Detailed examinations conducted under a stereomicroscope in May 1984 showed that 2-54\% of brood cells were infested with T. clareae in particular colonies (Tabl. 1). The average per colony infestation rate for 10 colonies examined was $24 \%$. Out of all 653 cells examined, mites were found in 132 cells $(20 \%)$. The following numbers of mites (nymphs and adults) were found in infested cells (Tabl. 2).

TABi. 1. - Tropilaelaps clareae (Tr) infestation of brood cells (\%),

of 100 brood individuals $(T r / B)$ and of 100 adult workers $(T r / W)$

\begin{tabular}{|c|c|c|c|c|c|c|}
\hline $\begin{array}{c}\text { Colony } \\
\text { No. }\end{array}$ & $\begin{array}{l}\text { No. Brood } \\
\text { cells } \\
\text { examin. }\end{array}$ & $\begin{array}{c}\% \text { brood } \\
\text { cells } \\
\text { infested }\end{array}$ & $\begin{array}{c}\text { Infestation } \\
\text { rate } \\
\mathrm{Tr} / \mathrm{B}\end{array}$ & $\begin{array}{l}\text { No. } \\
\text { workers } \\
\text { examin. }\end{array}$ & $\begin{array}{c}\text { Infestation } \\
\text { rate } \\
\operatorname{Tr} / W\end{array}$ & $\begin{array}{l}\text { Ratio } \\
\operatorname{Tr} / \mathrm{B}\end{array}$ \\
\hline 1 & 103 & 7.8 & 11.7 & 211 & 0.0 & - \\
\hline 2 & 100 & 2.0 & 2.0 & 216 & 0.5 & $\mathcal{A}$ \\
\hline 3 & 50 & 54.0 & 178.0 & 141 & 2.1 & 85 \\
\hline 4 & 50 & 20.0 & 40.0 & 149 & 6.7 & 6 \\
\hline 5 & 50 & 24.0 & 64.0 & 151 & 0.0 & - \\
\hline 6 & 50 & 18.0 & 40.0 & 147 & 0.7 & 57 \\
\hline 7 & 50 & 48.0 & 120.0 & 175 & 0.6 & 200 \\
\hline 8 & 50 & 28.0 & 62.0 & 189 & 1.6 & 39 \\
\hline 9 & 50 & 24.0 & 48.0 & 180 & 1.1 & 44 \\
\hline 10 & 100 & 13.0 & 23.0 & 215 & 1.4 & 16 \\
\hline $\begin{array}{l}\text { Total or } \\
\text { average }\end{array}$ & 653 & 24.1 & 58.9 & 1774 & 1.5 & \\
\hline
\end{tabular}

TABL. 2. - Frequency of infestation rates in brood cells

\begin{tabular}{|c|c|c|c|c|c|c|c|c|c|}
\hline Number of mites ..... & 1 & 2 & 3 & 4 & 5 & 6 & 7 & 8 & 11 \\
\hline Frequency $(\%)$ & 40.2 & 29.6 & 13.6 & 9.1 & 2.3 & 0.8 & 0.8 & 1.5 & 0.8 \\
\hline
\end{tabular}

The infestation rate (no. mites/100 brood cells investigated) varied from 2-178 in particular colonies. The average was $59 \%$ (Tabl. 1). The number of mites found on adult workers washed in petroleum varied from $0.6-6.7 / 100$ bees in particular colonies and the average was $1.5 / 100$ (Tabl. 1). All together 24 mites were found on the 1774 workers collected from 10 colonies, this is $1.4 / 100$ bees. No correlation was detected between infestation rate of brood and 
adult bees. From 4 to more than 200 times (average 40 times) more mites infested brood than adult bees.

An investigation was also carried out to compare brood infestation by $\boldsymbol{T}$. clareae in old and new combs. Colony No. 7 showed that $48 \%$ of brood cells in old combs were infested with mites, and the invasion rate of brood was 120 mites per 100 individuals. Only $16 \%$ of the brood cells in new combs were infested with mites, and the infestation rate was only $28 / 100$ individuals. So brood in comb used recently for bee rearing was 4.3 times more invaded in this case than that in a new comb.

Further examination of the same new comb revealed that $20 \%$ of drone cells were infested. The infestation rate was $28 / 100$ drone brood. So here no real difference between worker and drone brood infestation by $T$. clareae was found.

\section{Survival of $\mathrm{T}$. clareae on brood and adult workers}

The dorsum of $T$. clareae mite is hard but the venter is soft. Mites taken from brood cells were swollen to different degrees, apparently from hemolymph intake. Mites kept without food became slender, and the venter became concave at the time of death. Those mites which were more swollen at the beginning lived longer.

Observations of adult $T$. clareae mites put on combs with eggs did not show any evidence of feeding on eggs. Some of the mites kept at room temperature lived up to two days (Tabl. 2). No mites kept with eggs inside the hive survived until the next day.

In a series of 30 mites on pupae in test tubes, more than half survived 4 days and some more than 10 days (Tabl. 3). Surely they were feeding on the pupae.

Observations of mites put in test tubes with adult workers showed that just a touch of the mite with the tip of a foot of a worker bee, sufficed for the mite to attach itself to the bee very quickly. The bees made attempts to free themselves of the mites between thorax and abdomen, between thorax and head or in the ventral parts of the thorax or the abdomen near the thorax.

After about $8 \mathrm{~h}$ some mites became slender, lost interest in the bee and descended from it, apparently searching for something else. Out of two series of mites kept with adult workers at room temperature, 19-33\% survived till the next day. Only $25 \%$ of the mites in one series survived 2 days. No mite survived more than $60 \mathrm{~h}$. Out of three series of mites kept in an incubator or in bee colonies, none survived 1 day (Tabl. 3). 
TABL. 3. - Survival of Tropilaelaps clareae mises on honeybee brood and adults

\begin{tabular}{|c|c|c|c|c|c|c|c|c|c|c|c|c|}
\hline \multirow{2}{*}{$\begin{array}{c}\text { Series } \\
\text { No. }\end{array}$} & \multirow{2}{*}{$\begin{array}{l}\text { No. } \\
\text { examin. } \\
\text { mites }\end{array}$} & \multicolumn{10}{|c|}{$\%$ survival after hours (h) or days (d) } & \multirow{2}{*}{ Conditions } \\
\hline & & $12 \mathrm{~h}$ & $24 \mathrm{~h}$ & $36 \mathrm{~h}$ & $48 \mathrm{~h}$ & 60 & $3 \mathrm{c}$ & $4 d$ & $5 \mathrm{~d}$ & $9 \mathrm{~d}$ & $13 \mathrm{~d}$ & \\
\hline \multicolumn{13}{|c|}{ On comb with eggis only } \\
\hline $\begin{array}{l}1 \\
2 \\
3\end{array}$ & $\begin{array}{r}6 \\
10 \\
25\end{array}$ & $\begin{array}{l}50 \\
- \\
-\end{array}$ & $\begin{array}{r}33 \\
0 \\
0\end{array}$ & 一 & 20 & 0 & & & & & & $\begin{array}{l}\text { Room } \\
\text { Hive } \\
\text { Hive }\end{array}$ \\
\hline \multicolumn{13}{|c|}{ On pupae } \\
\hline 1 & 3 & - & 100 & - & 100 & - & 33 & 33 & 33 & & & Hive \\
\hline 2 & 30 & - & 80 & - & 70 & 一 & 57 & 53 & 30 & 7 & 3 & Hive \\
\hline \multicolumn{13}{|c|}{ On adult workers } \\
\hline 1 & 17 & 75 & 19 & 7 & 0 & & & & & & & Room \\
\hline 2 & 12 & 83 & 33 & - & 25 & 8 & 0 & & & & & Room \\
\hline 3 & 8 & - & 0 & & & & & & & & & Hive \\
\hline 4 & 6 & - & 0 & & & & & & & & & Hive \\
\hline 5 & 20 & - & 0 & & & & & & & & & Hive \\
\hline
\end{tabular}

These results show that $T$. clareae mites can not survive on adult bees more than 1-2 days.

\section{Combatting $\mathrm{T}$. clarcac by caging the queen for 9 days} and by destruction of sealed brood left in the colonies

Nine days after the queens were caged no open brood was present in the colonies. When cappings were cut out of the sealed brood, many mites were removed together with them. This method was tested in four colonies with a rate of brood infestation ranging from $12 / 100$ to $178 / 100$. In the first four days after removal of the cappings of the sealed brood numerous dead mites were found on the bottom board. In weaker colonies the removal of the damaged pupae from the comb was slow or insufficient. Some cells with intact pupae were resealed and had to be destroyed again.

Thus combatting $T$. clareae by cutting out cappings of sealed brood can be recommended only when the brood is immediately shaken out of the combs, and preferably only in stronger colonies. 


\section{Combatting $\mathrm{T}$. clareae by depriving colonies of brood}

Five bee colonies were investigated (No. 4, 6, 9 and 10. - Table 1 - and No. 12). Infestation of brood cells in those colonies varied from 13-24\% with brood infestation rates of $23-48 / 100$ and adult workers infestation rates of 0.7-6.7/100 (Tabl. 1).

All brood combs were removed from those colonies. Quecns in the first three colonics were caged for three days; queens in the other two were not caged. Ten days after the queens started to lay eggs in those broodless colonies, new sealed brood was present. Examination conducted after that period did not reveal $T$. clareae mites running on brood combs nor in 50 brood cells opened in each colony.

\section{Recommendation for combatting T. clareac without the use of drugs}

Based upon the fact that $T$. clareae can survive on adult bees for 1-2 days only, several methods to combat it may be recommended:

a) Remove all brood combs from infested bee colonies. This method is recommended especially for heavily infested weak bee colonies. A modification of this method is to make broodless nuclei.

b) Cage the queens for 9 days until all the brood will be sealed. After that time all cappings of sealed brood should be cut off and as much brood as possible should be shaken out. The queens should be released from the cages only after all remaining brood is removed from comb cells. This method can also be modified. After 9 days of caging the queens, the amount of brood will be reduced. So all the remaining brood can be removed and placed in other infested colonies that are queenlees or have caged queens.

c) Cage the queens at least 21 days. The amount of brood will decrease progressively. After all workers and drones emerge, cappings remaining on dead brood should be destroyed. The queen can be released after all cells are cleared of remaining brood.

\section{DISCUSSION}

According to AHMAD (1984) incidence of $V$. jacobsoni on $A$. cerana in neighboring Pakistan is very low as is the incidence of both $V$. jacobsoni and $T$. clareae on $A$. mellifera. $A$. dorsata, the host of $T$. clareae, occurs in the foot hills and plains in all provinces of Pakistan. Thus a source for infestation by both species of mites exists nearby. 
Previously $T$. clareae infestation on $A$. mellifera was found in regions populated by $A$. dorsata only (Burcert et al., 1984), but now it has also been found outside such areas.

The life span of adult $T$. clareae on combs with eggs or on adult workers (1-2 days) was found to be identical with the life span recorded for mites held without food (Akratanakul, 1984), and it is much shorter than the life span of 5-10 months recorded for $V$. jacobsoni on adult bees (LANGE et al., 1976 ; Smirnov, 1978 and Shabanov et al., 1978). According to these authors $V$. jacobsoni females repeatedly suck small portion of hemolymph at intervals without swelling. RAU (1980) presents a photo showing a swollen ventral part of that mite. $\boldsymbol{T}$. clareae mites were observed to be considerably swollen in this investigation. This shows they can ingest a large amount of hemolymph.

The percentage of infested brood cells, as well as infestation rates of 1-14 mites per cell are similar to data presented by Burcilet et al. (1983).

The overall infestation rate of adult bees (1.4 mites per 100 workers) as well as the maximum $(6.7 / 100)$ is much lower than that found for $V$. jacobsoni by different authors. This shows that $T$. clareae uses adult workers as a means of transportation and not as feeding source.

The recommended methods to combat $T$. clareae without the use of drugs are opposed to earlier publications which also recommended drug treatment in broodless colonies. The present investigation allows explanation of some kind of resistance existing in $A$. dorsata, the natural host of $T$. clareae. The population of $T$. clareae on adult bees increases when the amount of brood in the colonies decreases. Nevertheless the short life span of $T$. clareae on adult bees enables $A$. dorsata colonies to get rid of the mite during migration and of the beginning of comb construction, before the larvae appear. On the other hand, duc to the high rate of population increase, the mite can evidently live and reach high infestation levels in $A$. dorsata colonies despite the fact that they change their nest comb twice a year. However, it remains an unsolved problem how $T$. clareae is able to survive on adult $A$. dorsata bees during the migration period.

Results presented in this paper show that $T$. clareae can not survive in zones where interruption of brood rearing occcurs. Thus it does not seem likely that $T$. clareae can become a serious problem in temperate zones. Of course $T$. clareae may create problems in temperate areas like Afghanistan where continuous invasion from tropical areas can occur. 


\section{RÉSUME \\ LONGEVITE DE TROPILAELAPS CLAREAE ET LUTTE PREVENTIVE CONTRE CET ACARIEN QUI INFESTE LES COLONIES DAPIS MELLIFICA EN AFGHANISTAN}

L'introduction d'Apis mellifica en Asie tropicale n'a pas duré dans la plupart des cass plus d'un an ou deux. la principale difficulté est causée par Varroa jacobsoni, parasite naturel d'Apis cerana, et Tropilaelaps clareae, parasite naturel d'Apis dorsata, ce dernier étant considéré comme encore plus dangereux pour Apis mellifica. Nombreux sont ceux qui pensent que $T$. clareas survit en climat tempéré et qu'il pourrait done devenir un parasite excessivement dangercux pour $A$. mellifica.

On admet que la durée de vie de $T$. clareae est semblable à celle de $V$. jacobsoni. Il se reproduit dans les cellules de couvain operculé et les adultes doivent se nourrir de l'hémolymphe des abeilles adultes, mais la durée de vie de l'acarien sur les abeilles adultes est inconntic. l.e traitement consiste à retirer le couvain et enfumer la colonie.

Lors d'un séjour prolongé en Afghanistan (1982-1984), j'ai établi que, sur 3000 colonies d'A. mellifica du Ministère de l'Agriculture, $150(=5 \%)$ seulement étaient encore en vie. I.es: colonies $\mathrm{d}^{\prime} \boldsymbol{A}$. cerana, indigènes et donc acclimatées, n'existaient plus dans la région de Kaboul.

\section{Méthodes}

La présence de $T$. clareae a été mis en évidence sur couvain par désoperculation des cellules et sur abcilles adultes par lavage au pétrole. Afin de déterminer leur durée de vie, les acariens ont été prélevés dans les cellules au moyen d'allumettes taillées en pointe ou de pincettes, puis placés dans des boites de Pétri ou des éprouvettes sur divers substrats (morccilux de rayons avec œufs, nymphes, abeilles adultes). Pour combattre lacarien, on a claustré les reines d'abeilles dans des cages à l'intérieur de la colonie, ôté ou détruit par désoperculation le couvain operculé. Pour connaître le nombre d'acariens tombés sur le plancher, on a introduit dans la ruche une plaque de grillage avec dessous une feuille de papier.

\section{Résultats}

$V$. jacobsoni n’a pas été trouvé dans les colonies d'abeilles de la région de Kaboul, bien que ce parasite ait été observé l'année précédente. En ce qui concerne $T$. clareae, sa situation était très varjable : une partie des colonies était très fortement infestée et si affaiblie que certaines sont encore mortes au cours de l'été; par contre d'autres colonies se sont révélées totalement indemnes d'acariens et très fortes, au point qu'on a relevé des prises de poids journalières de $1,5 \mathrm{~kg}$. Ces colonies infestées avaient passé l'hiver dans une région chaude du pays avec une production de couvain constante, tandis que les colonies saines étaient restées à Kaboul, où elles avaient subi un repos hivernal, sans couvain, plus long. Les colonies non traitées et infestées de l'auteur, qui avaient hiverné à Kaboul pendant 2 mois, étaient au printemps indemnes d'acariens...

Dans les colonies infestées, $2-54 \%$ des cellules du couvain operculé renfermaient des acariens (moyenne $24 \%$, Tábl. 1). Le nombre d'acariens par cellule était de 1-4. L'infestation s'est élevée en moyenne à 59 acariens pour 100 nymphes (Tabl. 1). Les abeilles adultes par contre n'étaient en moyenne que faiblement infestées : 1,4/100 (0,0-6,7/100). L'infestation du couvain était donc 4 fois plus fo:te. Les rayons avec couvain étaient eux aussi 4,3 fois plus infestés que les rayons nouvellement construits.

Que ce soit sur les rayons avec cufs ou sur les abeilles adultes, les acariens n'ont pas vécu au-delà de 1 à 2 jours. Sur les nymphes, par contre, plus de la moitié des acariens a vécu 4 jours et quelques-uns jusqu'à 10 jours. Ces résultats prouvent que les acariens sont incapables de se nourrir de l'hémolymphe des abeilles adultes. 
On a expérimenté 3 méthodes de lutte :

1) Retrait de tous les cadres de couvain, ou formation de paquets d'abeilles sans couvain en les brossant des cadres. Quelques jours après le retrait de tout le couvain. les colonies étaient indemnes d'acariens.

2) Claustration de la reine pendant 9 jours, jusqu'à ce que tout le couvain soit operculé. Puis on le détruit en totalité et on secone les rayons pour expulser les nymphes. Cette méthode présente un inconvénient : les nymphes restantes ne sont parfois éliminées que lentement, surtout dans des colonies affaiblies.

3) Claustration de la reine pendant 21 jours, jusqu’à ce que tout le couvain soit éclos.

Il ne faut pas s’attendre à ce que $T$. clareae infeste des colonies d'A. mellifica dans les régions à climat tempéré, où il existe un arrêt de ponte pendant l'hiver, mais $T$. clarea peut causer de sévères problèmes à l'apiculture dans tous les pays tropicaux.

\title{
ZUSAMMENFASSUNG
}

\author{
ÜBERLEBEN UND PROPHYLAKTISCHE BEKAMPFUNG \\ VON TROPILAELAPS CLAREAE \\ IN VÖLKERN VON APIS MELLIFERA IN AFGHANISTAN
}

Die Einführung von Apis mellifera in das tropische Asien ist in den meisten Fällen nicht länger als für ein bis zwei Jahre gelungen. Die Hauptschwierigkeiten wurden von Varroa jacobsoni und Tropilaelaps clareae verursacht, wobei letztere als noch gefährlicher für Apis mellifera betrachtet wurde. Manche sind der Meinung, daß Tropilaelaps clareae auch in gemäßigtem Klima überleben und somit zu einer äußerst bedrohlichen Seuche für Apis mellifera werden könne. Im Gegensatz zu Varroa jacobsoni, ist Tropilaelaps clareae von der Riesenhonigbiene Apis dorsata auf Apis mellifera übergewechselt.

Man hat angenommen, daß der Lebenslauf von $T r$. clareae ähnlich verläuft wie der von V. jacobsoni. Die Reproduktion erfolgt in verdeckelten Brutzellen, die adulten Milben sollten sich vermutlich von der Haemolymphe der erwachsenen Bienen nähren, aber über die Lebensdauer der Milben auf erwachsenen Bienen war nichts bekannt. Die Behandlung erfolgte durch Entnahme der Brut und durch Beräucherung des Volkes.

Während eines längeren Aufenthaltes in Afghanistan (1982-1984) wurde festgestellt, daß von den 3000 mellifera- Völkern des Landwirtschaftsministeriums nur noch $150(=5 \%)$ am Leben waren. Völker der dort ursprünglich beheimateten Apis cerana waren in der Gegend von Kabul nicht mehr vorhanden.

\section{Methoden}

T. clareae wurde auf Brut durch Entdeckeln von Zellen und auf erwachsenen Bienen durch Auswaschen mit Petroleum festgestellt. Zur Bestimmung der Überlebensdauer der Milben wurden diese mittels eines zugespitzten Streichhölzchens oder mittels Pinzetten aus den Zellen entnommen und in Petrischalen oder Probengläsern auf verschiedene Substrate gesetzt (Wabenstücke mit Eiern, Puppen, erwachsene Bienen). Zur Bekämpfung wurden die Bienenköniginnen verschieden lange gesperrt und es wurde die verdeckelte Brut entweder entnommen oder durch Entdeckelung zerstört. Der Abfall von Milben wurde durch Einschieben von Folien in das Volk unter einem Gitternetz bestimmt. 


\section{Ergebnisse}

Die Untersuchung der Bienenvölker von Kabul ergab keinen Befall mit $V$. jacobsoni, obwohl das Vorkommen dieser Milhe im vorhergehenden Jahr beobachtet worden war. Das Bild hinsichilich des Tropilaelaps-Befalls war sehr uneinheitlich : Ein Teil der Völker war sehr stark befallea und sie waren so geschwächt, daß sie noch im Lauf des Sommers eingingen. Andere Völker hingegen erwiesen sich als völlig milbenfrei und sehr stark, so daß tägliche Gewichtsaınahmen von $1,5 \mathrm{~kg}$ beobachtet wurden. Die Aufzeichnung der Geschichte dieser Völker ergab, daß die befallenen Völker den Winter in einem warmen Landesteil bei stïndiger Bruttätigkeit verbracht hatte, während die gesunden in Kabul verblieben waren, wo sie eine längere brutfreie Winterpause darchgemacht hatten. Befallene untehandelte Völker, die der Autor in Kabul bei zwei Monaten Brutpausc ïbarwintert hatte, waren im Frühjahr milbenfrei.

In befallenen Völkern enthielten 2-54\% der verdeckelten Brutzellen Milben (Mittel $24 \%$. Tab. 1). Die Zahl der Milben pro Zelle betrug 1-4. Die Invasion betrug im Mittel 59 Milben pro 100 Puppen (Tab. 1). Die adulten Bienen hingegen waren im Mittel nur zu 1,4/100 (0,0-6,7/100) befallen : der Brutbefall war also $40 \mathrm{mal}$ höher. Schon bebrütete Waben waren $4,3 \mathrm{mal}$ stärker befallen als neu gebaute Waben.

Sowohl auf Waben mit Eiern wie auf adulten Bienen überlebten die Milben nicht länger als ein bis zwei Tage. Auf Puppen hingegen überlebte mehr als die Hälfte der Milben vier Tage und einige sogar länger als 10 Tage. Die Befunde können als Beweis dafür gelten, daß3 die Milben außerstande sind, sich von der Haemolymphe erwachsener Bienen zu ernähren.

Zur Bekümpfung der Milbe wurden drei Methoden erprobt :

1) Entnahme aller Brutwaben oder Bildung brutfreier Feglinge. Wenige Tage nach Entnahme sümtlicher Brut waren alle Völker frei von Milben.

2) Sperren der Königin für neun Tage, bis alle Brut verdeckelt ist. Dann wird alle ve:deckelte Brut zerstört und die Puppen werden aus den Waben geschüttelt. Diese Methode hat den Nachteil, daß manchmal die Keste der Puppen nur langsam entfernt werden, besonders bei geschwächten Völkern.

3) Käfigen der Königin für 21 Tage, bis die gesamte Brut geschlüpft ist.

Es ist nicht zu crwarten, daß $T$. clareae Völker von Apis mellifera in Gebieten mit gemäßigtem Klima befällt, wo während des Winters eine Brutunterbrechung erfolgt. Aber $T$. clareae kann für die Bienenzucht in allen Ländern mit tropischem Klima zu schweren P'roblemen führen.

\section{REFERENCES}

AHmad R., 1984. - Country status report on beekeeping in Pakistan. Proc. Expert Consultation on Beekeeping with Apis mellifera in Tropical and Sub-Tropical Asia. Bangkok/Chiang Mai, 203-210.

Akratanakul P., 1984. - Beekeeping industry with Apis mellifera in Thailand. Proc. Expert Consultation on Beekeeping with Apis mellifera in Tropical and Sub-Tropical Asia. Bangkok/ Chiang Mai, 222-234.

Burgett D.M., Krantz G.W., 1984. - The future of the European honey bee (Apis mellifera I.) in Southeast Asia, constrains of parasitism. Proc. Expert Consultation on Beekeeping with Apis mellifera in Tropical and Sub-Tropical Asia. Bangkok/Chiang Mai, 34-44.

Burgett M., Akratanakul P., Morse R.A., 1983. - Tropilaelaps clareae a parasite of honeybes in Southeast Asia. Bee W/d, 64 (1), 25-28. 
Crane E., 1968. - Mites infesting honeybees in Asia. Bee Wld, 49 (3), 113-114.

Kevan P.G., Morse R.A., Akratanakut. P., 1984. - Apiculture in tropical and sub-tropical Asia with special reference to European honey bees and development programmes. Proc. Expeit Consultation on Beckeeping with Apis mellifera in Tropical and Sub-Tropical Asia. Banghok/ Chiang Mai, 10-33.

Lange A.B. NackiJ K.V., TaciJ V., 1976. - [The mite Varroa and investigation on methods to control itl. Pchelovodsivo (3), 16-20 (in Russian).

Rau C., 1980. - Varroa - Weibchen von der Unterseite. Photographs. Allg. dtsch. Imkerztg., 14 (5), 168 a.

Shabanov M., Nedyalkov S., Toshkov A., 1978. - Varroatosis - A dangerous parasitic disease on bees. Am. Bee J., 118 (6), 402-437.

Smirnov A.M., 1978. - Research results obtained in USSR concerning etiology, pathogenesis, epizootology, diagnosis and control of Varroa disease in bees. Apiata, 13 (4), 149-162.

Worke J., 1984. - Beekeeping in Afghanistan. Proc. Expert Consultation on Beckeeping with Apis mellifera in Tropical and Sub-Tropical Asia Bangkok/Chiang Mai, Thailand, 124-131. 